\title{
Rocky coastal vegetation of the class Crithmo-Staticetea in the south-east of Italy
}

\author{
Valeria Tomaselli, Massimo Terzi* \\ Institute of Biosciences and Bioresources, CNR, via Amendola 165/A, Bari, Italy
}

\begin{abstract}
In the south-east of Italy, rocky coasts are almost entirely concentrated in the Apulia region. Several phytosociological papers have already dealt with the rocky coastal vegetation of the class Crithmo-Staticetea in some parts of the Apulian coast. However, there is still no overall revision carried out by using modern statistical treatments of phytosociological data. This paper aims to revise the syntaxonomy and nomenclature of the class Crithmo-Staticetea in the south-east of Italy. The revision is based on a data set of 225 relevés consisting of new and original phytosociological relevés (66) and others already published. The data matrix was classified with the use of flexible beta clustering. Indicator species analysis was employed to identify the indicator species of the main clusters of relevés. Results were interpreted from a syntaxonomic point of view. Non-metric multidimensional scaling ordination was performed in order to visualize the floristic relationships among associations. Rocky coastal vegetation of the Crithmo-Staticetea class in the south-east of Italy is represented by two orders, Crithmo maritimi-Staticetalia and Helichrysetalia italici. The first one includes two alliances, Crithmo-Staticion and Limonion anfracti-cancellati, with four associations and one, respectively. However, since they rely on very few character species, the floristic and syntaxonomic relationships between these two alliances need to be deepened by further investigations, involving a larger data set and investigation area. The second order, Helichrysetalia italici, includes two associations, well differentiated by their ecology, structure and floristic composition. For this reason, they were classified within two different alliances, Anthyllidion barbae-jovis and Helichrysion litorei. The Helichrysion litorei is here validated.
\end{abstract}

Keywords: Adriatic, coastal vegetation, Helichrysion litorei, limestone coasts, Mediterranean Basin, syntaxonomy, Crithmo-Staticetea

\section{Introduction}

Coastal environments have an important ecological value, providing ecosystem services essential to people and the environment (e.g. food provision, erosion control, water control, and habitats for many threatened and endangered species) and are worthy of attention and conservation. Coastal areas are one of the most threatened environments, both in the Mediterranean region and worldwide. In fact, especially in the last decades, they are undergoing rapid anthropogenic development. Increasing human pressure (e.g. urbanization, exploitation of natural resources, plant invasion) is causing coastal areas to diminish, in concert with the degradation and isolation of their habitats (Médail and Quézel 1997, Biondi 1999, Gibbs 2000, van der Maarel 2003, Underwood et al. 2009). The need to preserve these habitats was recognized by European policies so that they were included in Annex I of Directive 92/43/EEC, the 'habitat directive'. Cliffs and rocky coasts, identified by the habitat type code 1240 , 'Vegetated sea cliffs of the Mediterranean coasts with endemic Limonium spp.', are currently represented within many protected areas along the north Mediterranean Basin.

Vegetation of rocky coasts is composed of a typical flora, with halophilous chasmophytes and comophytes directly exposed to the action of marine aerosol, wind and waves, tolerating a high concentration of sodium chloride in the substrate and large temperature ranges. A large part of this vegetation belongs to the class Crithmo-Staticetea, which includes halophytic and halotolerant plant communities structurally formed by hemicryptophytes, chamaephytes and nanophanerophytes (Rivas-Martinez et al. 2002, Fanelli et al. 2004, Biondi et al. 2014). Among the character species, many

*Corresponding author, e-mail: massimo.terzi@ibbr.cnr.it 
Limonium species play a pivotal role, being represented by numerous endemics with a very restricted distribution area, and often including groups of vicariant species (Dolcher and Pignatti 1971, Diana 1992). Due to the presence of such endemics, most of the associations of the Crithmo-Staticion have endemic closely regional distribution. Along the coasts of the Mediterranean Basin, and up to the Black Sea, the class is traditionally represented by only one order (Crithmo-Staticetalia), whilst another two have been described for the European Atlantic coasts (Crithmo-Armerietalia maritimae, habitat code 1230), the Canary Island, the Azores and Morocco (Frankenio-Astydamietalia, habitat code 1250). A fourth order, Helichrysetalia italici, was described to represent the sub-aerohaline coastal dwarf scrub vegetation on the inland edges of the Mediterranean coasts (Mucina et al. 2016).

The coastline of the Italian Peninsula extends over nearly $8000 \mathrm{~km}$. The Apulia region is characterized by nearly 900 $\mathrm{km}$ of coast and represents the region of the Italian peninsula with the longest coastline (Giandonato 2003). Many phytosociological surveys have been carried out along the Apulian coast, on both sandy and rocky shores (e.g., Cristofolini et al. 1967, Curti and Lorenzoni 1968, Corbetta 1970, Caniglia et al. 1984, Géhu et al. 1984, Corbetta et al. 1989, Bartolo et al. 1992, Brullo and De Marco 1989, Mariotti et al. 1992, Beccarisi et al. 2003, Biondi et al. 2006, Corbetta et al. 2006, Biondi and Casavecchia 2010, Tomaselli et al. 2011, Pirone 2014, Sciandrello and Tomaselli 2014). The vegetation of the rocky coasts was classified in several associations of the orders Crithmo-Staticetalia, Helichrysetalia italici and Senecionetalia cinerariae. Since the rocky coasts of the south-east of Italy are almost entirely concentrated in the Apulian region (Biondi, 1999), these associations are representative of the class Crithmo-Staticetea in the south-east of Italy.

This paper aims to revise the syntaxonomy and nomenclature of the class Crithmo-Staticetea in the south-east of Italy and to establish the floristic, coenological, syntaxonomic and synchorological relationships among its associations. Several phytosociological papers have already dealt with this vegetation type in some parts of the Apulian coast (e.g. Cristofolini et al. 1967, Curti and Lorenzoni 1968, Bartolo et al. 1992, Biondi et al. 2006); however, there is still no overall revision carried out by using modern statistical treatments of phytosociological data. To this end, new original phytosociological data, sampled from the Gargano Promontory to the tip of the Salento Peninsula, and already published data were analysed together. Moreover, since different syntaxonomic schemes of the Crithmo-Staticetea have been proposed for this area, the results have been discussed in the light of these different interpretations.

\section{Materials and methods}

This revision is based on a data set consisting of 225 relevés from the Apulia region (Fig. 1). Some of these relevés (123) were taken from phytosociological literature (Tab. 1), selecting those that have already been classified in the Crith-

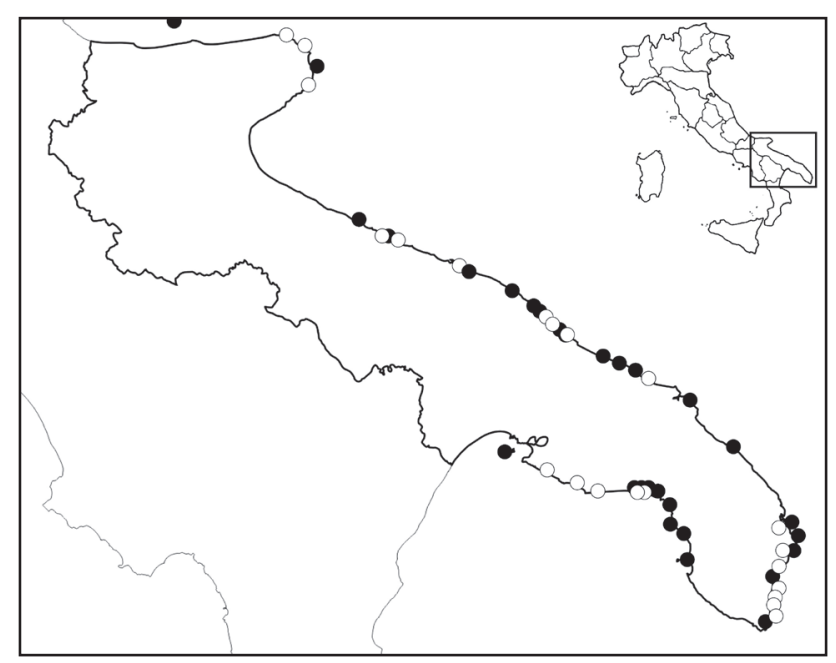

Fig. 1. Map of the study area (Apulia region, south-east of Italy) with indications of the relevés' locations. Empty circles indicate the new relevés; full circles indicate relevés taken from phytosociological literature (see Tab. 1).

mo-Staticetea class. Another 33 relevés published by Biondi et al. (2006) and describing two communities dominated by Arthrocaulon macrostachyum (= Arthrocnemum macrostachyum), namely 'Arthrocnemum macrostachyum community' and 'Limonio virgati-Arthrocnemetum macrostachyi', were added to the data set in order to define the syntaxonomic and floristic relationships with the Crithmo-Staticetea class, and clarify the typical zonation of the Apulian rocky coast vegetation. In fact, these communities were originally classified in the Arthrocnemion glauci alliance of the class Salicornietea fruticosae but show floristic and habitat similarities with vegetation of the Crithmo-Staticetea growing in a close catenal relationship. For analogous reasons, we also added to the data set another three relevés assigned to the Salicornietea fruticosae by Mariotti et al. (1992). The data set includes also 66 new relevés carried out in rocky coastal habitats, along the distribution area of four Apulian endemic Limonium species (Fig. 1, On-line Suppl. Tab. 1). Three of them, L. apulum, L. diomedei and L. japygicum, were frequently recorded in the relevés whereas the fourth, L. peucetium, was not found. This latter was originally identified by Pignatti (1982) from old plant material collected in the 19 th century along the rocky coast near Bari where, however, it is no longer observed (Wagensommer et al. 2014, Bartolucci et al. 2018).

The new relevés were collected by using the Braun-Blanquet approach (Westhoff and van der Maarel 1980). For each sample, geographical coordinates, slope, exposure, distance from the shoreline, total vegetation cover and plot size, the latter ranging from 10 to $50 \mathrm{~m}^{2}$, were detected. Species abundance-dominance values were estimated in the field by using the Braun-Blanquet scale.

Considering the entire set of relevés, the average plot size turned out to be $43.5 \mathrm{~m}^{2}$, with a median of $20 \mathrm{~m}^{2}$ and minimum and maximum values of 5 and $500 \mathrm{~m}^{2}$, respectively. 
Tab. 1. Data sources of relevés of the Crithmo-Staticetea class and Limonio-Arthrocnemetum (Arthrocnemion glauci) from Apulia region, south-east of Italy, taken from phytosociological literature and included in the data set. Bibliographic source, number of relevés (No.), and original classification (at association/alliance level) are reported.

\begin{tabular}{lrl}
\hline Source & No. & Association and alliance as reported in the original paper \\
\hline Bartolo et al. (1992: tab. 9, rel. 1-6) & 6 & 'Crithmo-Limonietum apuli', 'Crithmo-Limonion' \\
Bartolo et al. (1992: tab. 10, rel. 1-9) & 9 & Limonietum japygici, 'Crithmo-Limonion' \\
Bartolo et al. (1992: tab. 11, rel. 1-20) & 20 & Crithmo-Limonietum diomedei, 'Crithmo-Limonion' \\
Bartolo et al. (1992: tab. 12, rel. 1-8) & 8 & Limonio virgati-Plantaginetum grovesii, 'Crithmo-Limonion' \\
Bartolo et al. (1992: tab. 15, rel. 1-16) & 16 & Agropyro-Helycrisetum italici, 'Plantagini-Thymelaeion hirsutae' \\
Biondi et al. (2006: tab. 8, rel. 1-18) & 18 & 'Arthrocnemum macrostachyum comm.', 'Arthrocnemion macrostachyi' \\
Biondi et al. (2006: tab. 9, rel. 1-11) & 11 & Limonio virgati-Arthrocnemetum macrostachyi, 'Arthrocnemion macrostachyi' \\
Biondi et al. (2006: tab. 9, rel. 12-15) & 4 & Limonio virgati-Arthrocnemetum macrostachyi subass. crithmetosum maritimi, \\
Biondi et al. (2006: tab. 10, rel. 1-7) & 7 & Limonietum japygici, 'Crithmo-Limonion' \\
Biondi et al. (2006: tab. 11, rel. 1-3) & 3 & Limonietum japygici subass. capparidetosum spinosae, 'Crithmo-Limonion' \\
Biondi et al. (2006: tab. 13, rel. 1-12) & 12 & Crithmo maritimi-Inuletum crithmoidis, 'Crithmo-Limonion' \\
Brullo and De Marco (1989: tab. 3, rel. 34-42) & 9 & Anthyllido-Centaureetum diomedeae, 'Anthyllidion barbae-jovis' \\
Caniglia et al. (1984: tab. 16, rel. 1-9) & 9 & 'Limonietum japygici subass. a Salicornia e Inula', 'Crithmo-Staticion s.l' \\
Cristofolini et al. (1967: tab. 1, rel. 1-6) & 6 & 'Crithmo-Staticetalia' \\
Curti and Lorenzoni (1968: tab. 2, rel. 6-9) & 4 & Limonietum japygici typicum, 'Crithmo-Staticion' \\
Curti and Lorenzoni (1968: tab. 2, rel. 10-17) & 8 & 'Limonietum japygici subass. a Salicornia fruticosa e Inula crithmoides', 'Crithmo- \\
Mariotti et al. (1992: tab. 5, rel. 29-31) & 3 & 'Aggr. a Limonium virgatum e Sarcocornia fruticosa', 'Limonion galloprovincialis' \\
Mariotti et al. (1992: tab. 10, rel. 53-54) & 2 & 'Frankenio laevis-Limonietum cancellati', 'Crithmo-Limonion' \\
Mariotti et al. (1992: tab. 10, rel. 55-58) & 4 & 'Frankenio laevis-Limonietum cancellati' 'subass. sarcocornietosum fruticosae', \\
& & 'Crithmo-Limonion' \\
\hline
\end{tabular}

Relevés sampled on extremely large $\left(>100 \mathrm{~m}^{2}\right)$ and extremely small $\left(<10 \mathrm{~m}^{2}\right)$ plots were excluded from the data analysis, since they could have affected the results of statistical analyses (see Otýpková and Chytrý 2006). Taxa recorded only at the genus level as well as lichens and bryophytes were omitted from the data set. Taxon scores originally recorded according to the Braun-Blanquet scale, were replaced with the ordinal scale as proposed by van der Maarel (1979). The resulting data matrix consisted of 205 relevés sharing 115 taxa.

Relevés were hierarchically clustered by using flexible beta linkage, with the Bray-Curtis coefficient. Beta was set at -0.25 so that flexible beta clustering became a space-conserving method (McCune and Grace 2002). The dendrogram was pruned at the level yielding the highest number of indicator species (IndSp). To this end, indicator species analysis (ISA, Dufrêne and Legendre 1997) was run for the first 20 partitioning levels of the resulting dendrogram, further divisions dealing with minor variations. A taxon was considered as the IndSp of a cluster for a given partition if its indicator value (IndVal, Dufrêne and Legendre 1997) turned out to be higher for that cluster than for the others of the same partition. The statistical significance $(p<0.01)$ of IndVal was assessed by means of a Monte Carlo test with 10000 permutations.

In order to enhance the interpretability of the results, each IndSp was assigned to only one cluster of relevés along the hierarchical descending typologies of the dendrogram, that is to the cluster for which the IndVal of that taxon first reached its maximum value (Dufrêne and Legendre 1997, see also Terzi 2015). Two taxa yielded the highest value for the first trivial partition with all the relevés in one cluster (Fig. 2, cluster C1), and they were considered as diagnostic for the Crithmo-Staticetea class.

The clusters of relevés were interpreted from a syntaxonomical viewpoint, on the basis of the occurrence of nomenclatural type-relevés within each of them. Diagnostic species of syntaxa were selected from the IndSp of the relevant cluster or of its subdivisions.

The relevés were also ordinated by means of nonmetric multi-dimensional scaling (NMDS), using the Bray-Curtis coefficient as a dissimilarity measure. The whole of the statistical analysis described above was carried out by using PC-Ord software, version 6.22 (McCune and Mefford, 2011). For NMDS, the 'slow and thorough' option of the auto-pilot mode provided in PC-Ord was used.

Taxonomic nomenclature follows Bartolucci et al. (2018), except for Plantago holosteum Scop. subsp. grovesii (Beg.) Brullo. In fact, the taxonomic status of this taxon is controversial and requires further in-depth studies, being considered as a species by Conti et al. (2005, 'Plantago grovesii'), as a subspecies of Plantago holosteum by Brullo (1988) and as a synonym of Plantago subulata by Hassemer et al. (2017).

Syntaxonomic nomenclature follows Mucina et al. (2016), except where indicated. The nomenclatural decisions were taken according to the $3^{\text {rd }}$ edition of the International Code of Phytosociological Nomenclature (ICPN, Weber et al. 2000), whose articles (art) are cited within brackets. 


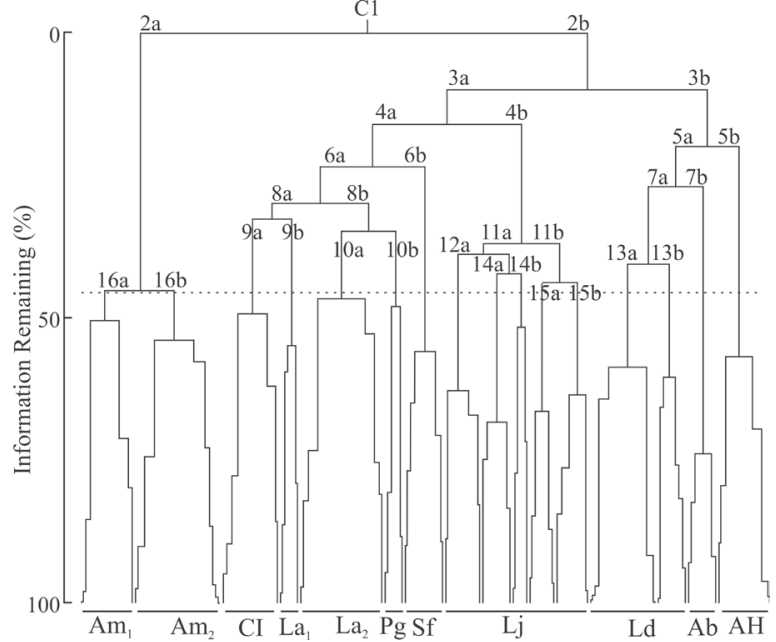

Fig. 2. Flexible beta clustering of relevés of the Crithmo-Staticetea class and Limonio-Arthrocnemetum (Arthrocnemion glauci) from Apulia region, south-east of Italy. Each cluster of the first 16 partitions of the dendrogram, is identified by a two digit code: the number refers to the partitioning level, while the letters ('a' or 'b') identify the two clusters originating at that partition. The first trivial partition, with all the relevés in only one group, is indicated as 'C1'. Ab - Anthyllido barbae-jovis-Centaureetum diomedeae; $\mathrm{AH}$ - Agropyro pungentis-Helichrysetum italici; $\mathrm{Am}_{1 / 2}$ - Limonio virgati-Arthrocnemetum macrostachyi; CI: Crithmo maritimi-Inuletum crithmoidis; $\mathrm{La}_{1 / 2}$ - Crithmo maritimi-Limonietum apuli; $\mathrm{Ld}$ : Crithmo maritimi-Limonietum diomedei; $\mathrm{Lj}$ - Limonietum japygici typicum; Pg - Limonio virgati-Plantaginetum grovesii; Sf - relevés with Salicornia fruticosa.

\section{Results}

The dendrogram was pruned to give 16 clusters of relevés (Fig. 2). Few clusters turned out to be clearly differentiated from the others by having a high number of IndSp (e.g., clusters 5b, 7b); most have no or few IndSp (Fig. 3). Therefore, only 9 out of these 16 clusters can be considered as representative of associations, the others representing only minor variations without syntaxonomic relevance. Cluster 2a includes the relevés dominated by Arthrocaulon macrostachyum. Further subdivision of this cluster does not show a clear distinction between the 'Arthrocnemum macrostachyum community' and 'Limonio virgate-Arthrocnemetum macrostachyi, the relevés of these two community types being mixed together in clusters 16a and 16b. The relevés of these clusters are characterized by very low species richness (1-6 taxa for relevés), with four IndSp: Arthrocaulon macrostachyum, Halimione portulacoides, Limonium narbonense and Juncus maritimus (Fig. 3).

The relevés with Limonium apulum are grouped in clusters $9 \mathrm{~b}$ and 10a. Few IndSp characterize these clusters and, with the exception of $L$. apulum, all of them have a low IndVal and are usually considered diagnostic for other vegetation types (e.g., Suaeda vera for the salt-marsh shrub vegetation of the Salicornietea fruticosae, Parapholis incurva for the therophytic vegetation of the Saginetea maritimae). Cluster 9 a has no IndSp and includes relevés dominated by Limbarda crithmoides subsp. longifolia and without Limonium apulum.

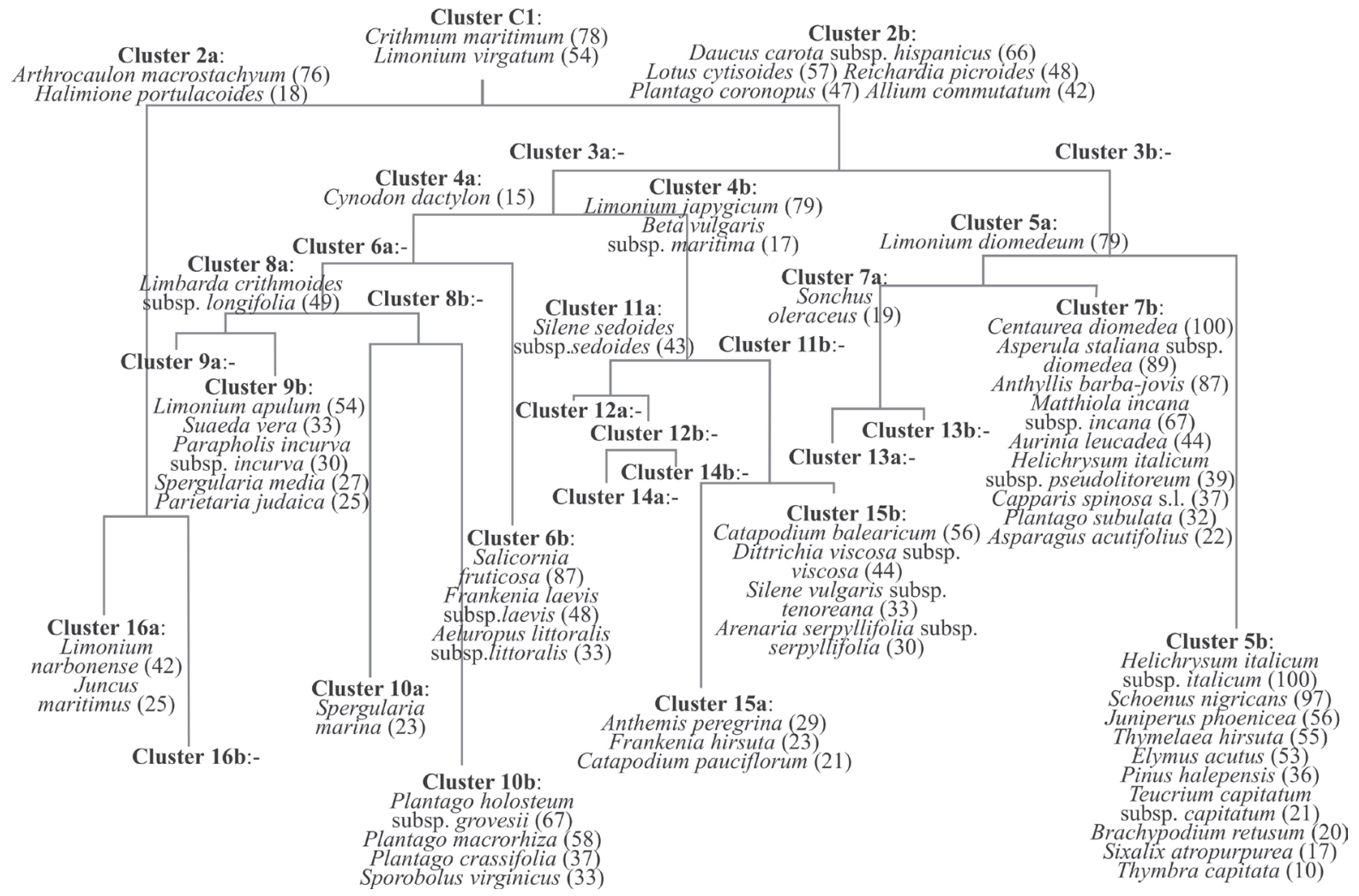

Fig. 3. Results of the indicator species analysis, according to Dufrêne and Legendre (1997), for the first 16 partitioning levels of the dendrogram (see Fig. 2). Indicator species associated to each cluster are reported together with the corresponding indicator values (within brackets). Each cluster of the dendrogram is identified by a two digit code: the number refers to the partitioning level, while the letters ('a' or 'b') identify the two clusters originating at that partition. The first trivial partition, with all the relevés in only one group, is indicated as 'C1'. 
This cluster represents the Crithmo-Inuletum. Cluster 10b includes the relevés of the Limonio-Plantaginetum grovesii that is a typical aspect of coastal vegetation, developing in a restricted area on marls near Otranto. This cluster is characterized by several IndSp, such as Plantago holosteum subsp. grovesii, Pl. macrorhiza and Pl. crassifolia.

Cluster $4 \mathrm{~b}$ and its subdivisions represent the Limonietum japygici. Few IndSp are associated with these clusters and they do not support the identification of more than one subassociation, the typical one. A second subassociation is represented by cluster $6 \mathrm{~b}$, which includes relevés already classified in the subassociation 'a Salicornia e Inula' by Curti and Lorenzoni (1968) and Caniglia et al. (1984) together with others previously assigned to the 'Frankenio laevis-Limonietum cancellati subass. sarcocornietosum fruticosae' by Mariotti et al. (1992).

The relevés from the Gargano and Tremiti coasts are grouped in cluster $3 \mathrm{~b}$. The three main subdivisions of this cluster represent the Agropyro-Helichrysetum italici (cluster 5b), Anthyllido-Centaureetum diomedeae (7b) and CrithmoLimonietum diomedei (7a), respectively. The first two associations turned out to be differentiated by many IndSp, some of them having a high IndVal (Fig. 3). The Crithmo-Limonietum diomedei (7a) is recognizable for the occurrence of the sole Limonium diomedei, and its two sub clusters (13a and 13b) are not associated to any IndSp.

The NMDS ordination resulted in a three-axis solution, with a final stress of 14.7. The three axes accounted for 71.3\% of the variance in the Bray-Curtis dissimilarity matrix (first axis $47.8 \%$, second axis $11.7 \%$ and third axis $11.9 \%$ ). In the NMDS diagram (Fig. 4), axis 1 clearly separates the commu-

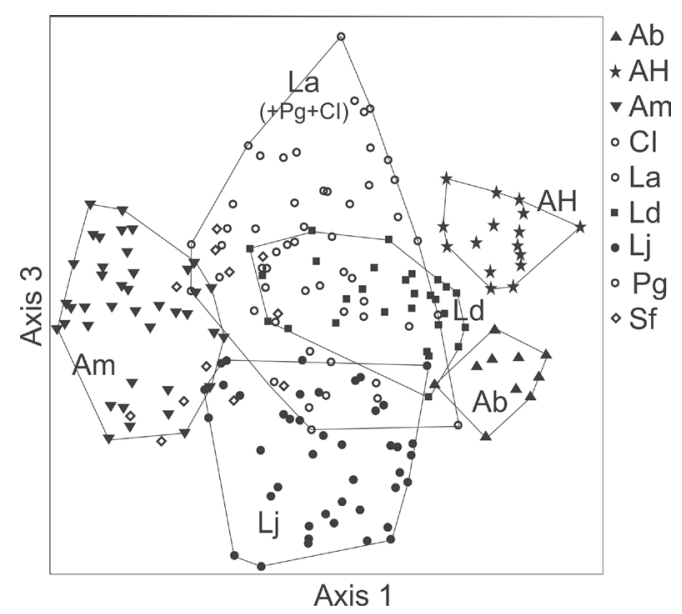

Fig. 4. Nonmetric multi-dimensional scaling ordination of relevés of the Crithmo-Staticetea class and Limonio-Arthrocnemetum (Arthrocnemion glauci) from the Apulia region, south-east of Italy. Ab - Anthyllido barbae-jovis-Centaureetum diomedeae; AH - Agropyro pungentis-Helichrysetum italici; Am - Limonio virgati-Arthrocnemetum macrostachyi; CI - Crithmo maritimi-Inuletum crithmoidis; La - Crithmo maritimi-Limonietum apuli; Ld - Crithmo maritimiLimonietum diomedei; $\mathrm{Lj}$ - Limonietum japygici typicum; $\mathrm{Pg}-\mathrm{Li}$ monio virgati-Plantaginetum grovesii; Sf - relevés with Salicornia fruticosa. nities dominated by Arthrocaulon macrostachyum (Am) on one side, and Agropyro-Helichrysetum italici (AH), Anthyllido-Centaureetum diomedeae $(\mathrm{Ab})$ and Crithmo-Limonietum diomedei $(\mathrm{Ld})$ on the other. In the middle, there are the other vegetation types without clear separation among them (a similar situation is observed on the diagram for axis 1 and 2 - data not shown). Axis 3 roughly separates the relevés of the Limonietum japygici (filled circular marks in Fig. 4: Lj), concentrated in the lower part of the diagram, from those of the Crithmo-Limonietum apuli (La), Limonio-Plantaginetum grovesii $(\mathrm{Pg})$ and Crithmo-Inuletum (CI), which are in the upper part. Results of the NMDS ordination approximately confirm the general syntaxonomic pattern highlighted by the cluster analysis.

A synoptic table (Tab. 2) summarizes the nine groups identified, with the percentage frequency for each species in each plant community.

\section{Discussion}

The syntaxonomic classification of the rocky coastal vegetation of the Italian peninsula has been subjected to numerous changes and revisions in the last decades. In a thorough survey on the Crithmo-Staticetea class, Bartolo et al. (1992) reported two alliances of the order Crithmo-Staticetalia for the Italian peninsula, Crithmo-Staticion and Plantagini-Thymelaeion hirsutae, with the first one including the halophilous pioneer communities next to the coastline, and the second one including halotolerant shrub vegetation, located towards the hinterland and in catenal contact with the Crithmo-Staticion. The Plantagini-Thymelaeion hirsutae was, however, originally invalidly published (art. 5, 8 and $3 g$ ICPN). Subsequently Mayer (1995: 101) explicitly listed the diagnostic taxa of the alliance - as required by article 8 of the ICPN. However, the alliance remained invalid because it is unclear from what Plantago species the alliance name is formed (art 3g) and because it still lacks the nomenclatural type (art. 5). Brullo and De Marco (1989) described another alliance, Anthyllidion barbae-jovis, for the halotolerant nanophanerophytic vegetation of vertical high cliffs next to the coast, including this syntaxon in the order Crithmo-Staticetalia. Subsequently, the Anthyllidion barbae-jovis and Plantagini-Thymelaeion hirsutae were moved to the Helichrysetalia italici, of the class Helichryso-Crucianelletea maritimae (Biondi et al. 1997, Biondi 1999). In a subsequent contribution, Biondi (2007) separated the chasmophytic halophilous pioneer vegetation of the Crithmo-Staticetalia from the chomophytic and halotolerant vegetation dominated by chamaephytes as well as nanophanerophytes, clearly distinct from both an ecological and a physiognomic-structural point of view (see Fanelli et al. 2004), and described a new order, Senecionetalia cinerariae, for these last communities. The alliance Anthyllidion barbae-jovis was thus attributed to this new order, whilst halotolerant dwarf shrub communities were included in the Helichrysion litorei, of the Helichrysetalia italici (Biondi 2007; Biondi et al. 2014). As pointed out by Biondi et al. (2013), the Helichrysion litorei was originally 
Tab. 2. Abridged synoptic table of the Crithmo maritimi-Staticetea class in the south-east of Italy (taxon scores represent the taxa percentage frequencies). Columns: I - Arthrocaulon macrostachyum group (Limonio virgati-Arthrocnemetum macrostachyi); II - Limbarda crithmoides group (Crithmo maritimi-Inuletum crithmoidis); III - Limonium apulum group (Crithmo-Limonietum apuli); IV - Plantago holosteum subsp. grovesii group (Limonio virgati-Plantaginetum grovesii); V - Salicornia fruticosa group (Limonietum japygici salicornietosum fruticosae); VI - Limonium japygicum group (Limonietum japygici); VII - Limonium diomedeum group (Chrithmo-Limonietum diomedei); VIII - Anthyllis barba-jovis group (Anthyllido-Centauretum diomedeae); IX - Helichrysum italicum group (Agropyro-Helichrysetum italici).

\begin{tabular}{|c|c|c|c|c|c|c|c|c|c|}
\hline Group & I & II & III & IV & $\mathrm{V}$ & VI & VII & VIII & IX \\
\hline No. of relevès & 42 & 23 & 25 & 6 & 12 & 43 & 29 & 9 & 16 \\
\hline \multicolumn{10}{|l|}{ Char. and diff. species of associations } \\
\hline Limonium apulum & 0 & 0 & 90 & 0 & 25 & 0 & 0 & 0 & 0 \\
\hline Plantago holosteumsubsp. grovesii & 0 & 0 & 0 & 67 & 0 & 0 & 0 & 0 & 0 \\
\hline Limonium japygicum & 21 & 12 & 0 & 0 & 50 & 98 & 0 & 0 & 0 \\
\hline Centaurea diomedea & 0 & 0 & 0 & 0 & 0 & 0 & 0 & 100 & 0 \\
\hline Asperula staliana subsp. diomedea & 0 & 0 & 0 & 0 & 0 & 0 & 0 & 89 & 0 \\
\hline Aurinia leucadea & 0 & 0 & 0 & 0 & 0 & 0 & 0 & 44 & 0 \\
\hline \multicolumn{10}{|l|}{ All. Limonion anfracti-cancellati } \\
\hline Limonium diomedeum & 2 & 0 & 0 & 0 & 0 & 0 & 100 & 44 & 13 \\
\hline \multicolumn{10}{|c|}{ Cl. Crithmo-Staticetea, ord. Crithmo-Staticetalia, all. Crithmo-Staticion } \\
\hline Crithmum maritimum & 31 & 100 & 97 & 100 & 33 & 86 & 100 & 100 & 94 \\
\hline Limonium virgatum & 43 & 65 & 84 & 100 & 100 & 51 & 41 & 0 & 19 \\
\hline Plantago macrorrhiza & 0 & 0 & 0 & 67 & 0 & 12 & 0 & 0 & 0 \\
\hline Lotus cytisoides & 0 & 29 & 58 & 50 & 17 & 56 & 86 & 78 & 94 \\
\hline Frankenia hirsuta & 12 & 24 & 32 & 0 & 8 & 33 & 7 & 0 & 0 \\
\hline Allium commutatum & 0 & 6 & 32 & 33 & 0 & 5 & 45 & 56 & 69 \\
\hline Daucus carota subsp. hispanicus & 0 & 6 & 3 & 50 & 0 & 7 & 62 & 89 & 94 \\
\hline Frankenia laevis subsp. laevis & 14 & 6 & 6 & 0 & 67 & 2 & 0 & 0 & 0 \\
\hline Plantago holosteum subsp. scopulorum & 0 & 0 & 0 & 0 & 0 & 0 & 17 & 56 & 19 \\
\hline Senecio leucanthemifolius subsp. leucanthemifolius & 0 & 0 & 0 & 0 & 0 & 0 & 3 & 0 & 0 \\
\hline Reichardia picroides & 0 & 29 & 29 & 67 & 0 & 37 & 62 & 78 & 75 \\
\hline \multicolumn{10}{|c|}{ Ord. Helichrysetalia italici, all. Anthyllidion barbae-jovis and all. Helichrysion litorei } \\
\hline Anthyllis barba-jovis & 0 & 0 & 3 & 0 & 0 & 0 & 0 & 89 & 0 \\
\hline Matthiola incana subsp. incana & 0 & 0 & 0 & 0 & 0 & 0 & 0 & 67 & 0 \\
\hline Helichrysum italicum subsp. pseudolitoreum & 0 & 0 & 0 & 0 & 0 & 0 & 17 & 56 & 0 \\
\hline Helichrysum italicum subsp. italicum (d) & 0 & 0 & 0 & 0 & 0 & 0 & 0 & 0 & 100 \\
\hline Thymelaea hirsuta & 0 & 0 & 0 & 0 & 0 & 0 & 0 & 0 & 62 \\
\hline \multicolumn{10}{|c|}{ Cl. Salicornietea fruticosae, ord. Salicornietalia fruticosae, all. Arthrocnemion glauci } \\
\hline Arthrocaulon macrostachyum & 100 & 54 & 58 & 0 & 8 & 37 & 48 & 0 & 0 \\
\hline Limbarda crithmoides subsp. longifolia & 19 & 100 & 19 & 33 & 67 & 19 & 10 & 0 & 0 \\
\hline Suaeda vera & 7 & 54 & 13 & 0 & 0 & 2 & 28 & 0 & 13 \\
\hline Halimione portulacoides & 24 & 24 & 0 & 0 & 17 & 7 & 0 & 0 & 0 \\
\hline Salicornia fruticosa & 7 & 0 & 0 & 0 & 92 & 0 & 0 & 0 & 0 \\
\hline Limonium narbonense & 21 & 0 & 0 & 0 & 8 & 0 & 0 & 0 & 0 \\
\hline Puccinellia festuciformis subsp. festuciformis & 2 & 0 & 0 & 0 & 0 & 0 & 0 & 0 & 0 \\
\hline
\end{tabular}

invalidly described because the sole association of its original diagnosis, the Senecioni-Helichrysetum litorei Barbagallo, Brullo et Signorello 1983, had been in turn invalidly published, it being unclear from what Senecio species the association name was formed (art. 3g). Biondi (in: Biondi et al. 2013) described the new association 'Senecioni bicoloris-Helichrysetum litorei' (cf art. 6) but failed to validate the alliance Helichrysion litorei. In fact, Biondi (in: Biondi et al. 2013) designated as nomenclatural type of the alliance the invalid 'Senecioni-Helichrysetum litorei Barbagallo, Brullo et Signorello 1983' instead of the new and valid Senecioni bicolorisHelichrysetum litorei Biondi in Biondi et al. 2013.
More recently, Mucina et al. (2016) proposed a new classification scheme. According to this contribution, two orders of the Crithmo-Staticetea can be recognized for the Italian peninsula: the Crithmo-Staticetalia for the rupicolous vegetation of salt-sprayed cliffs, and the Helichrysetalia italici for the sub-aerohaline coastal dwarf scrub on the inland edges of salt-sprayed cliffs of the seaboards. Within the Crithmo-Staticetalia, two alliances are recognized: Crithmo-Staticion for the rupicolous dwarf-herb vegetation of salt-sprayed limestone cliffs of the Tyrrhenian and Ligurian coasts, and Limonion anfracti-cancellati for the rupicolous herb-rich vegetation of salt-sprayed rocky cliffs of the Adriatic coasts. The 
Plantagini-Thymelaeion hirsutae and Helichrysion litorei are dealt with as syntaxonomic synonyms of the Anthyllidion barbae-jovis, within the Helichrysetalia italici. According to the syntaxonomic proposal of Mucina et al. (2016), the associations Limonio virgati-Plantaginetum grovesii, CrithmoLimonietum apuli, Crithmo maritimi-Inuletum crithmoidis and Limonietum japygici should be classified in the CrithmoStaticion, whilst the Crithmo-Limonietum diomedei has to be ascribed to the Adriatic alliance Limonion anfracti-cancellati. On the other hand, the Anthyllido-Centauretum diomedeae and Agropyro-Helichrysetum italici should be classified in the Anthyllidion barbae-jovis which encompasses both the nanophanerophytic vegetation of the high cliffs (Anthyllido-Centauretum diomedeae) and the coastal dwarf scrub communities (Agropyro-Helichrysetum italici). However, these two vegetation types are characterized by different structures and ecological requirements, and in the end by a different floristic composition. The clusters representing these two associations turned out to be clearly distinguished, being separated both in the ordination diagram (Fig. 4) and in the dendrogram (Fig. 2). Moreover, each of them was characterized by many IndSp, indicating their floristic autonomy (Fig. 3). Therefore, in our opinion, these two associations should be kept at least in separate alliances, as already proposed by other authors (Biondi 2007; Pirone 2014; Biondi et al. 2014). As a consequence, the Helichrysion litorei is here validated (see below) and the Agropyro-Helichrysetum italici is classified in this alliance.

As regards the spatial distribution and vegetation zonation of the rocky coasts, several belts can be described (Fig. 5 and 6). In a thorough analysis of the coastal vegetation of the Salento peninsula (South Apulia), Biondi et al. (2006) described a first belt, subject to continuous salt-water spraying and characterized by plant communities formed by succulent chamaephytes or nanophanerophytes such as Arthrocaulon macrostachyum (Arthrocaulon macrostachyum communities and Limonio virgati-Arthrocnemetum macrostachyi) or by Limbarda crithmoides (Crithmo maritimi-Inuletum crithmoidis), depending on the geological nature of the substrate (cluster 16a-16b and 8a in Fig. 2). Although these communities with Arthrocaulon macrostachyum develop on rocky substrates and in close catenal contact with communities of the Crithmo-Staticetea class, they were originally classified in the Arthrocnemion glauci, of the Salicornietea fruticosae class (Biondi et al. 2006). In our analyses, this vegetation type turned out to be well differentiated from all the other types (Fig. 2) and characterized by few IndSp, most of them of the Salicornietea fruticosae class. In two previous contributions about the vegetation of some coastal sites of Southern Apulia, Curti and Lorenzoni (1968) described a subassociation of the Limonietum japygici with 'Salicornia fruticosa e Inula crithmoides' whereas Mariotti et al. (1992) described the subassociation sarcocornietosum fruticosae of the Frankenio laevis-Limonietum cancellati (here considered as a synonym of the Crithmo-Limonietum apuli). In our numerical analyses, these relevés segregate into a group (6b) characterized by Salicornia fruticosa and including both subassociations. The first subassociation could be considered as a halophilous aspect of the Limonietum japygici, subject to periodic submersion with stagnation of sea water, due to the low elevation above sea level (see below). However, as regards the subassociation 'sarcocornietosum fruticosaei' of the Frankenio laevis-Limonietum cancellati, described by Mariotti et al (1992) in the site of Torre Guaceto, it is necessary to point out that, during our surveys in Torre Guaceto and other coastal sites of the same area, in the same habitat types we have found Arthrocaulon macrostachyum instead of Salicornia fruticosa. Therefore, we suppose that the Frankenio laevis-Limonietum cancellati salicocornietosum fruticosae could actually refer to a transition between the Crithmo-Limonietum apuli and $\mathrm{Li}$ monio virgati-Arthrocnemetum macrostachyi.

Following the zonation, the belt immediately towards the inland is occupied by plant communities characterized by the presence of Limonium sp.pl. (Figs. 5 and 6). In the Apulian region, four vicariant and endemic associations have been described. The Limonietum japygici is distributed along the south-western part of the Apulian coast and is characterized by Limonium japygicum, endemic to the Salento peninsula, from Taranto to Otranto (LE) (Pignatti 1971, Pignatti et al. 2014). This association was invalidly published by Curti and Lorenzoni (1968) because its name-giving taxon, Limonium japygicum, had not been validly published. This taxon has recently been validated (Pignatti et al. 2014), and consequently the Limonietum japygici and its two subassociations (typicum and sarcocornietosum fruticosae) are here validated. Based on the results of our revision, these two subassociations are sufficient to describe the floristic variability of this association. The Crithmo-Limonietum apuli, extend-

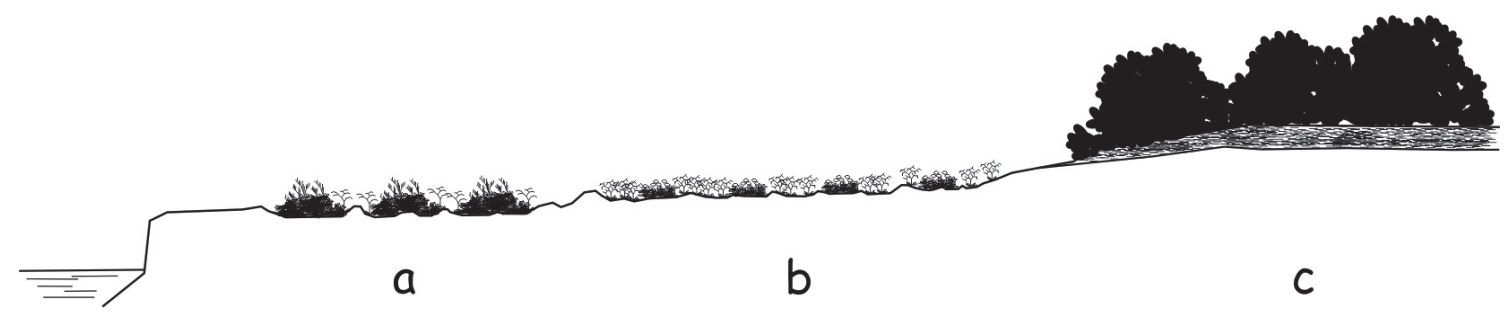

Fig. 5. Schematic outline of the distribution of plant communities on rocky coasts of central-southern Apulia: a) Arthrocnemion glauci (Limonio virgati-Arthrocnemetum macrostachyi)/Crithmo maritimi-Staticion (Crithmo-Inuletum crithmoidis); b) Crithmo maritimi-Staticion (Limonietum japygici in southern Apulia / Crithmo-Limonietum apuli in central Apulia); c) Juniperion turbinatae or Oleo-Ceratonion. 
ing along the Adriatic coast of Apulia from Otranto to the Gargano peninsula, is characterized by Limonium apulum, a taxon belonging to the $L$. cancellatum group and endemic to the Adriatic coast of the Apulia region (Brullo et al. 1990, Bogdanović et al. 2012). This association was effectively published in 1992, although the year 1989 is reported on the first page of the article by Bartolo et al. (1992). In the same year, another association, Frankenio laevis-Limonietum cancella$t i$, was described for Torre Guaceto for a similar habitat type (Mariotti et al. 1992). According to the results of our analysis, these two associations should be united. In fact, the nomenclatural types of the Crithmo-Limonietum apuli and Frankenio laevis-Limonietum cancellati were grouped in the same cluster (Fig. 2: cluster $\mathrm{La}_{2}$ ). Having no information about the month of publication of the two volumes where these associations were validly published (vol. 47 of Candollea and vol. 19 of Colloques Phytosociologiques, both published in 1992), we choose to retain the name Crithmo-Limonietum apuli. In fact, Limonium cancellatum, one of the name-giving taxa of the other association, was excluded from the flora of Italy (Wagensommer et al. 2012) so that Frankenio laevis-Limonietum cancellati turns out to be incorrect.

The Limonio virgati-Plantaginetum grovesii is a restricted endemic association that develops on marl substrates near the Alimini Lakes (Otranto), within the distribution range of the Crithmo-Limonietum apuli. It is characterized by Plantago holosteum subsp. grovesii and differentiated by the higher frequency and cover of Plantago macrorhiza and $\mathrm{Pl}$. crassifolia. The Limonio virgati-Plantaginetum grovesii could be considered a geographic vicariant of the Plantagini holostei-Staticetum cancellatae (i.e. the lectotype of the Limo- nion anfracti-cancellati, cf. Mucina et al. 2016) that has been recorded in numerous localities along the Croatian coasts (Horvatić 1934, 1939, Pandža et al. 2007, Stančić et al. 2008).

The Crithmo-Limonietum diomedei is characterized by Limonium diomedeum which is endemic to the Tremiti islands and Gargano Peninsula (Perrino and Wagensommer 2011) and is considered as a vicariant of L. vestitum which is endemic to the Kamik islet of the Vis archipelago in central Dalmatia (Brullo 1988, Bogdanović and Brullo 2015). Following the syntaxonomic scheme proposed by Mucina et al. (2016), this association has been here classified in the Limonion anfracti-cancellati. Nevertheless, this last attribution relies on the presence of one only diagnostic species of the alliance, that is, Limonium diomedeum. More generally, the floristic differences between this alliance and the Crithmo-Staticion rely on few character/differential stenoendemic taxa. For this reason, in our opinion, further investigations are required in order to confirm the autonomy of the Limonion anfracti-cancellati as a distinct alliance.

A third zone, sheltered from the direct action of marine waters, is characterized by halotolerant shrub communities, with different ecologies and structures (Fig. 6). The AgropyroHelichrysetum italici garrigues are discontinuously distributed along the Adriatic coasts of Apulia, in some localities near Brindisi and along the Gargano and Tremiti coasts. This association makes catenal contact with the Crithmo-Limonietum apuli, and with the Crithmo-Limonietum diomedei, depending on the geographic zone. The Anthyllido-Centaureetum diomedeae Brullo et De Marco 1990, on the high cliffs of the Gargano Peninsula and Tremiti islands, makes catenal contact with the Crithmo-Limonietum diomedei communities.

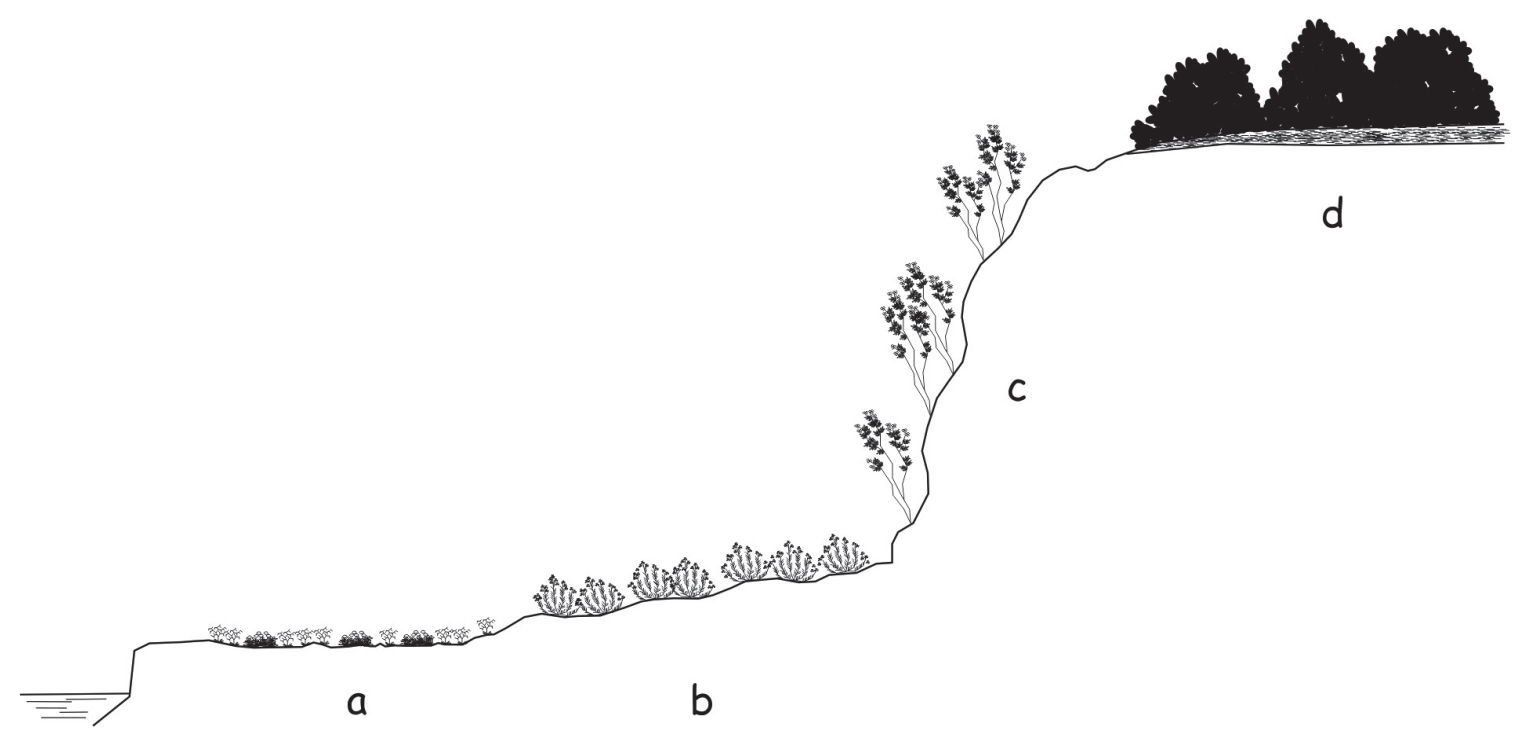

Fig. 6. Schematic outline of the distribution of plant communities on rocky coasts of northern Apulia (Gargano and Tremiti Islands): a) Limonion anfracti-cancellati (Crithmo maritimi-Limonietum diomedei); b) Helichrysion litorei (Agropyro pungentis-Helichrysetum italici); c) Anthyllidion barbae-jovis (Anthyllido barbae-jovis-Centaureetum diomedeae); d) Juniperion turbinatae or Oleo-Ceratonion. 


\section{Syntaxonomic scheme}

CL. Crithmo maritimi-Staticetea Br.-Bl. in Br.-Bl. et al. 1952*

ORD. Crithmo maritimi-Staticetalia Molinier $1934^{*}$

All. Crithmo maritimi-Staticion Molinier $1934^{*}$

Limonietum japygici Curti et Lorenzoni ex Tomaselli et Terzi ass. nov hoc loco [holotypus: see below the Limonietum japygici typicum; synonym: Limonietum japygici Curti et Lorenzoni 1968 (art. 31)]

Limonietum japygici typicum subass. nov. hoc loco [holotypus rel. 49 of the on-line Supplement Tab. S1, 15 May 2014, locality Ponte Ciolo (LE), Italy: Allium commutatum +, Capparis spinosa s.l. +, Catapodium balearicum +, Crithmum maritimum 3, Dittrichia viscosa subsp. viscosa +, Elymus acutus 1, Limonium japygicum 1, Lotus cytisoides 1, Silene sedoides subsp. sedoides +, Silene vulgaris subsp. tenoreana 1]; Limonietum japygici salicornietosum fruticosae subass. nov. hoc loco [holotypus rel. 14, tab. 2, in Curti and Lorenzoni 1968: 887];

Crithmo maritimi-Limonietum apuli Bartolo, Brullo et Signorello 1992 [syn. Frankenio laevis-Limonietum cancellati Mariotti et al. 1992]

Crithmo maritimi-Inuletum crithmoidis Biondi, Casavecchia et Guerra 2006

Limonio virgati-Plantaginetum grovesii Bartolo, Brullo et Signorello 1992

AlL. Limonion anfracti-cancellati (Horvatić 1934) Mucina in Mucina et al. 2016

Crithmo maritimi-Limonietum diomedei Bartolo, Brullo et Signorello 1992

OrD. Helichrysetalia italici Biondi et Géhu in Géhu et Biondi 1994

All. Anthyllidion barbae-jovis Brullo et De Marco 1989

Anthyllido barbae-jovis-Centaureetum diomedeae Brullo et De Marco 1989

AlL. Helichrysion litorei Biondi ex Tomaselli et Terzi all. nov. hoc loco [holotypus: Senecioni bicoloris-Helichrysetum litorei Biondi in Biondi, Allegrezza, Casavecchia, Galdenzi, Gigante et Pesaresi 2013 (p. 189); diagnostic taxa (cf. Biondi 2007): Helichrysum litoreum, Helichrysum italicum subsp. pseudolitoreum, Helichrysum italicum subsp. italicum (diff.), Jacobaea maritima subsp. bicolor, Thymelaea hirsuta; Synonyms: Plantagini-Thymelaeion hirsutae Bartolo et Brullo in Bartolo, Brullo et Signorello 1992 nom. inval. (art. 3g, 5, 8); Plantagini-Thymelaeion hirsutae Bartolo et Brullo ex Mayer 1995 (art. 3g, 5); Helichrysion litorei Biondi 2007 nom. inval. (art. 5); Helichrysion litorei Biondi in Biondi, Allegrezza, Casavecchia, Galdenzi, Gigante et Pesaresi 2013 nom. inval. (art. 5)]

Agropyro pungentis-Helichrysetum italici Bartolo, Brullo et Signorello 1992

CL. Salicornietea fruticosae Br.-Bl. et Tx. ex A. de Bolos y Vayreda et O. de Bolos in A. de Bolos y Vayreda 1950 OrD. Salicornietalia fruticosae Br.-Bl. 1933

All. Arthrocnemion glauci Rivas-Mart. et Costa M. 1984

Limonio virgati-Arthrocnemetum macrostachyi Biondi, Casavecchia et Guerra 2006

*As already pointed out by Mucina et al. 2016, the presence of more than one species of the genus Limonium in the original diagnoses of the Crithmo-Staticetea, Crithmo-Staticetalia and Crithmo-Staticion, do not allow the addition of any epithet to the original forms of the names. However, since only one species of the genus Crithmum occurs (i.e. Cr. maritimum), the epithet has been added.

\section{Acknowledgements}

We thank Jean-Paul Theurillat and Laco Mucina for their help in resolving a nomenclatural issue. We are also grate-

\section{References}

Barbagallo, C., Brullo, S., Signorello, P., 1983: Note fitosociologiche sulla vegetazione delle isole Eolie. Bollettino dell'Accademia Gioenia di Scienze Naturali 16, 7-16.

Bartolo, G., Brullo, S., Signorello, P., 1992: La classe Crithmo-Limonietea nella penisola Italiana. Colloques phytosociologiques $19,55-81$. ful to two anonymous referees for their comments and suggestions.
Bartolucci, F., Peruzzi, L., Galasso, G., Albano, A., Alessandrini, A., Ardenghi, N.M.G., Astuti, G., Bacchetta, G., Ballelli, S., Banfi, E., Barberis, G., Bernardo, L., Bouvet, D., Bovio, M., Cecchi, L., Di Pietro, R., Domina, G., Fascetti, S., Fenu, G., Festi, F., Foggi, B., Gallo, L., Gottschlich, G., Gubellini, L., Iamonico, D., Iberite, M., Jiménez-Mejías, P., Lattanzi, E., Mar- 
chetti, D., Martinetto, E., Masin, R.R., Medagli, P., Passalacqua, N.G., Peccenini, S., Pennesi, R., Pierini, B., Poldini, L., Prosser, F., Raimondo, F.M., Roma-Marzio, F., Rosati, L., Santangelo, A., Scoppola, A., Scortegagna, S., Selvaggi, A., Selvi, F., Soldano, A., Stinca, A., Wagensommer, R.P., Wilhalm, T., Conti, F., 2018: An updated checklist of the vascular flora native to Italy. Plant Biosystems 152, 179-303.

Beccarisi, L., Medagli, P., Minonne, F., Zuccarello, V., Marchiori, S., 2003: Descrizione ed analisi fitostorica della vegetazione del sito di Torre Guaceto. Thalassia Salentina 27, 99-116.

Biondi, E., Vagge, I., Mossa, L., 1997: On the phytosociological importance of Anthyllis barba jovis L. Colloques phytosociologiques 27, 95-104.

Biondi, E., 1999: Diversità fitocenotica degli ambienti costieri italiani. Bollettino del Museo Civico di Scienze Naturali di Venezia suppl. 49, 39-105.

Biondi, E., Casavecchia, S., Guerra, V., 2006: Analysis of vegetation diversity in relation to the geomorphological characteristics in the Salento coasts (Apulia - Italy). Fitosociologia 43, 25-38.

Biondi, E., 2007: Thoughts on the ecology and syntaxonomy of some vegetation typologies of the Mediterranean coast. Fitosociologia $44,3-10$.

Biondi, E., Casavecchia, S., 2010: The halophilous retro-dune grasslands of the Italian Adriatic coastline. Braun-Blanquetia $46,11-127$.

Biondi, E., Allegrezza, M., Casavecchia, S., Galdenzi, D., Gigante, D., Pesaresi, S., 2013: Validation of some syntaxa of Italian vegetation. Plant Biosystems 147, 186-207.

Biondi, E., Blasi, C., Allegrezza, M., Anzellotti, I., Azzella, M.M., Carli, E., Casavecchia, S., Copiz, R., Del Vico, E., Facioni, L., Galdenzi, D., Gasparri, R., Lasen, C., Pesaresi, S., Poldini, L., Sburlino, G., Taffetani, F., Vagge, I., Zitti, S., Zivkovic, L., 2014. Plant communities of Italy: The Vegetation Prodrome. Plant Biosystems 148, 728-814.

Bogdanović, S., Liber, Z., Šatović, Z. \& Nikolić, T., 2012: Phylogeography of the Adriatic Limonium cancellatum complex (Plumbaginaceae) - evidence from AFLP. In: Rešetnik, I., Bogdanović, S., Alegro, A., (eds.), International Symposium on Evolution of Balkan Biodiversity, Book of abstract. Zagreb, BalkBioDiv Consortium and Croatian Botanical Society, p. 37.

Bogdanović, S., Brullo, S., 2015: Taxonomic revision of the Limonium cancellatum group (Plumbaginaceae) in Croatia. Phytotaxa $215,1-87$.

Brullo, S. 1988: Note tassonomiche sulla flora pugliese (Italia meridionale). Braun-Blanquetia 2, 31-32.

Brullo, S., De Marco, G., 1989: Antyllidion barbae-jovis alleanza nuova dei Crithmo-Limonietea. Archivio Botanico Italiano 65, 109-120.

Brullo, S., Guglielmo, A., Terrasi, M.C., 1990: Osservazioni citotassonomiche su alcune specie di Limonium dell'Italia meridionale. Giornale Botanico Italiano 124, 122.

Caniglia, G., Chiesura Lorenzoni, F., Curti, L., Lorenzoni, G.G., Marchiori, S., Razzara, S., Tornadore Marchiori, N., 1984: Contributo allo studio fitosociologico del Salento meridionale (Puglia - Italia meridionale). Archivio Botanico e Biogeografico Italiano 60, 1-40.

Conti, F., Abbate, G., Alessandrini, A., Blasi, C., 2005: An annotated checklist of the Italian vascular Flora. Ministero dell'Ambiente e della Tutela del Territorio, Direzione per la Protezione della Natura. Palombi Editore, Roma, Italy.

Corbetta, F., 1970: Lineamenti della vegetazione macrofitica dei Laghi di Lesina e Varano. Giornale Botanico Italiano 104, 165-191.
Corbetta, F., Gratani, L., Morioni, M., Pirone, G., 1989: Lineamenti vegetazionali e caratterizzazione ecologica delle spiagge dell'Arco Jonico da Taranto alla Foce del Sinni. Colloques Phytosociologique 19, 461-521.

Corbetta, F., La Monica, M., Pirone, G., Burri, E., Ivona, A., 2006: La vegetazione delle Saline di Margherita di Savoia (Puglia). Micologia e Vegetazione Mediterranea 21, 141-156.

Cristofolini, G., Lausi, D., Tarabocchia, M., Pignatti, S. 1967: Flora e vegetazione dell'Isola di Pianosa (Isole Tremiti). Giornale Botanico Italiano 101, 189-198.

Curti, L., Lorenzoni, G.G., 1968: Ricerche sulla vegetazione dell'Isola Grande (Porto Cesareo - Lecce). Atti e relazioni. Accademia Pugliese delle Scienze 26, 865-904.

Diana, S., 1992: Alcuni aspetti della biologia della riproduzione del genere Limonium. Giornale Botanico Italiano 126, $187-$ 195.

Dolcher, T., Pignatti, S., 1971: Un'ipotesi sull'evoluzione dei $L i$ monium del Bacino del Mediterraneo. Giornale Botanico Italiano 105 , 95-107.

Dufrêne, M., Legendre, P., 1997: Species assemblages and indicator species: the need for a flexible asymmetrical approach. Ecological Monographs 67, 345-366.

Fanelli, G., Serafini Sauli, A., Tescarollo, P., 2004: Halotolerant and halophytic vegetation from cliffs in Central Mediterranean Peninsular Italy with emphasis on Southern Lazio. Phytocoenologia 34, 447-464.

Géhu, J.M., Costa, M., Scoppola, A., Biondi, E., Marchiori, S., Peris, J.B., Frank, J., Caniglia, G., Veri, L., 1984: Essai synsystématique et synchorologique sur les végétations littorales italiennes dans un but conservatoire. Documents Phytosociologiques n. s. 8, 393-474.

Giandonato P.B., 2003: Il mare in Puglia. Agenzia Regionale per la Protezione Ambientale della Puglia (A.R.P.A. Puglia), Lecce, Italy.

Gibbs, J. P., 2000: Wetlands loss and biodiversity conservation. Conservation Biology 14, 314-317.

Hassemer, G., Meudt, H. M., Rønsted, N., 2017: Nomenclatural and taxonomic notes on Mediterranean narrow-leaved plantains (Plantago section Maritima, Plantaginaceae). Webbia 72, 197-205.

Horvatić, S., 1934: Flora and vegetation of Pag island. Prirodoslovna istraživanja 19, 116-372 (in Croatian).

Horvatić, S., 1939: An overview of the vegetation of Rab island from a plant sociology point of view. Prirodoslovna istraživanja 22, 1-99 (in Croatian).

Mayer, A., 1995: Comparative study of the coastal vegetation of Sardinia (Italy) and Crete (Greece) with respect to the effects of human influence. IHW-Verlag, Eching bei München, DE.

Mariotti, M. G., Braggio Morucchio, G., Cornara, L., Placereani, S., 1992: Studio fitosociologico e palinologico della vegetazione attuale e del passato a Torre Guaceto (Puglia, Italia meridionale). Candollea 47, 31-60.

McCune, B., Grace, J. B., 2002: Analysis of ecological communities. MjM Software, Gleneden Beach, Oregon, US.

McCune, B., Mefford, M. J., 2011: PC-ORD. Multivariate analysis of ecological data. Version 6.22. MjM Software, Gleneden Beach, Oregon, US.

Médail, F., Quézel, P., 1997: Hot-Spots analysis for conservation of plant biodiversity in the Mediterranean Basin. Annals of the Missouri Botanical Garden 84, 112-127.

Mucina, L., Bültmann, H., Dierßen, K., Theurillat, J.-P., Raus, T., Čarni, A., Šumberová, K., Willner, W., Dengler, J., Gavílan García, R., Chytrý, M., Hájek, M., Di Pietro, R., Iakushenko, D., Pallas, J., Daniëls, F.J.A., Bergmeier, E., Santos Guerra, A., Ermakov, N., Valachovic, M., Schaminée, J.H.J., Lysenko, T., Didukh, Y.P., Pignatti, S., Rodwell, J.S., Capelo, J., Weber, H.E., Solomeshch, A., Dimopoulos, P., Aguiar, C., Hennek- 
ens, S.M., Tichý, L., 2016: Vegetation of Europe: hierarchical floristic classification system of vascular plant, bryophyte, lichen, and algal communities. Applied Vegetation Science 19 (S1), 3-264.

Otýpková, Z., Chytrý, M., 2006: Effects of plot size on the ordination of vegetation samples. Journal of Vegetation Science 17, 465-472.

Pandža, M., Franjić, J., Škvorc, Ž., Idžojtić, M., 2007: Syntaxonomical and synchorological analysis of the Crithmo-Limonietea Br.-Bl. 1947 on the Eastern Adriatic coast. Periodicum Biologorum 109, 61-66.

Perrino, E.V., Wagensommer, R.P., 2011: Schede per una Lista Rossa della Flora vascolare e crittogamica Italiana: Limonium diomedeum Brullo. Informatore Botanico Italiano 43, 381458.

Pignatti, S., 1971: Studi sui Limonium, VIII. In: Heywood VH, ed. Florae Europaea. Notulae systematicae ad Flora Europaeam spectantes. Botanical Journal of the Linnean Society 64 , 353-381.

Pignatti, S., 1982: New species of Limonium from Italy and Tunesia. Webbia 36, 47-56.

Pignatti, S., Galasso, G., Nicolella, G., 2014: Notulae alla checklist della flora vascolare italiana 17: notula 2062. Informatore Botanico Italiano 46, 71-86.

Pirone, G., 2014: Notes on the vegetation diversity on the Adriatic and Ionian Italian coasts: the dunes and cliffs. Plant Sociology 51 Suppl. 1, 7-18.

Rivas-Martínez, S., Díaz, T. E., Fernández-González, F., Izco, J., Loidi, J., Lousã, M., Penas, A., 2002: Vascular plant communitiea of Spain and Portugal. Addenda to the syntaxonomical checklist of 2001. Itinera Geobotanica 15, 5-922.
Sciandrello, S., Tomaselli, V., 2014: Coastal salt-marshes plant communities of the Salicornietea fruticosae class in Apulia (Italy). Biologia 9, 53-69.

Stančić, Z., Brigić, A., Liber, Z., Rusak, G., Franjić, J., Škvorc, Ž., 2008: Adriatic coastal plant taxa and communities of Croatia and their threat status. Acta Botanica Gallica 155, 179-199.

Terzi, M., 2015: Numerical analysis of the order Scorzoneretalia villosae. Phytocoenologia 45, 11-32.

Tomaselli, V., Di Pietro, R., Sciandrello, S., 2011: Distribution, structure and ecology of coastal wetlands plant communities in southern Apulia (Italy). Biologia 66, 1027-1043.

Underwood, E.C., Viers, J.H., Klausmeyer, K.R., Cox, R.L., Shaw, M.R., 2009: Threats and biodiversity in the mediterranean biome. Diversity and Distributions 15, 188-197.

van der Maarel, E., 1979: Transformation of cover-abundance values in phytosociology and its effects on community similarity. Vegetatio 39, 97-114.

van der Maarel, E., 2003: Some remarks on the functions of European coastal ecosystems. Phytocoenologia 33, 187-202.

Wagensommer, R.P., Perrino, E.V., Brullo, S., 2012: Notulae alla checklist della flora vascolare italiana 13: notulae 1898-1899. Informatore Botanico Italiano 44, 178-179.

Wagensommer, R.P., Perrino, E.V., Medagli, P., 2014: Limonium peucetium Pignatti. Informatore Botanico Italiano 46, 285-321.

Weber, H.E., Moravec, J., Theurillat, J.-P., 2000: International code of phytosociological nomenclature. Journal of Vegetation Science 11, 739-768.

Westhoff, V., van der Maarel, E., 1980: The Braun-Blanquet approach. In: Whittaker, R.H. (ed.), Classification of plant communities, $2^{\text {nd }}$ edition, 287-399. Junk, The Hague, NL. 